\title{
Gazdaságtudományi képzés a magyar felsôoktatásban a statisztikai adatok tükrében
}

\section{Training in Economics in Hungarian Higher Education in the Light of Statistics}

\section{ÖSSZEFOGLALÁS}

A felsôoktatás gazdaságtudományi képzési területén érintettek állandó kihívásokkal néznek szembe: változó jogszabályi, gazdasági környezet, a munkaerôpiac egyre specifikusabb és növekvố elvárásai, a Z generációs hallgatók motivációi, attitúdje, szakmai kompetenciakövetelmények, a globalizáció kihívásai és az egyetemek között folyó verseny az egyre szúkülô piacon is folyamatos megújulásra kényszeríti a szereplóket. Tanulmányunkban helyzetképet kívánunk nyújtani a magyarországi gazdaságtudományi felsôoktatásról a szereplôk piaci részesedése, képzési kínálata és struktúrája tekintetében. Elsôdleges célunk bemutatni a magyarországi gazdaságtudományi felsôoktatásra jellemzó erôs és gyenge pontokat, illetve a hosszú távon fenntartható, folyamatosan megújulásra képes felsôoktatásban rejlő lehetôségeket és veszélyeket.
Journal of Economic Literature (JEL) kódok: A2, I2, M4

Kulcsszavak: felsôoktatási szektor, számviteloktatás, oktatási módszerek, innováció, fenntarthatóság

\section{SUMMARY}

In higher education teachers of economics constantly face challenges: ever increasing and increasingly specific labour market expectations, the different attitudes and motivations of generation $\mathrm{Z}$ students, changing professional competence requirements, the legal and the business environment, the challenges of globalisation and, last but not least, competition between universities. These factors all trigger innovation. This study intends to provide a comprehensive view of teaching economics at higher education institutions in Hungary, with focus on the market share

Dr. Siklósi ÁGnes PhD, egyetemi docens, Budapesti Gazdasági Egyetem PSZK (siklosi.agnes@uni-bge.hu), DR. Sisa Krisztina A. PhD, fóiskolai docens, Budapesti Gazdasági Egyetem PSZK (sisa.krisztina@uni-bge.hu). 
of participants, and the content, forms and structures of training. The strengths and weaknesses of tertiary economics education in Hungary are shown along with the opportunities and threats encountered in a higher educational system capable of innovation and sustainable over the long term.

Journal of Economic Literature (JEL) codes: A2, I2, M4

Keywords: higher education sector, teaching accounting, teaching methods, innovation, sustainability

\section{A MAGYAR FELSŐOKTATÁSI SZEKTOR NEMZETGAZDASÁGI SZEREPE}

A magyar oktatásügy, oktatáspolitika jelentôs változáson megy keresztül, de azt tényként megállapíthatjuk, hogy a felsőoktatás által kibocsátott szellemi elit képzése minden nemzet számára kiemelkedó jelentôségú feladat. A megfelelôen kvalifikált munkaerô a mindenkori kormányzat gazdaság- és társadalompolitikai céljait szolgálja, így az állami szerepvállalás a felsôoktatásban elengedhetetlen. Cél a felsôoktatás színvonalának emelése, ami azzal jár, hogy meg kell teremteni a versenyképes tudás átadásához és megszerzéséhez szükséges feltételrendszert. A felsôoktatás rendszerének múködtetése az állami feladatellátás funkcionális csoportosítási szempontja alapján az állam jóléti feladataként valósul meg. Az állami finanszírozás mellett viszont éppen a felsôoktatás területén a leginkább jellemzô és a legjelentôsebb a magánfinanszírozás szerepe. Magyarországon a jelenlegi felsôoktatási finanszírozási rendszer vegyes rendszernek tekinthetô, amelyben egyaránt jelen van az állami finanszírozás - más néven adófinanszírozás - és az önköltséges finanszírozási rendszer - magánfinanszírozás - is. A felsôoktatási szektorban tükrözôdô állami szerepvállalás mértékét jól szemlélteti az oktatási feladatra fordított „állami pénzköltés" mértéke is, amelyet leginkább az oktatási kiadások GDP-hez viszonyított aránya szemléltet.

Az 1. táblázat adatai alapján elmondható, hogy a költségvetés oktatásra fordított összkiadása és ezen belül a felsôfokú oktatásra fordított kiadása folyó áron számítva a vizsgált idôszakban 2008-ig folyamatos növekedést mutatott, majd egy megtorpanást, illetve csökkenést követôen ismét növekvô pályára állt. A GDP-hez viszonyított arány esetében egyértelmú a folyamatos csökkenés. A költségvetési kiadás mértékének megítélését segíti a nemzetközi összehasonlítás is (1. ábra).

$\mathrm{Az}$ 1. ábrában szereplố államok GDP-arányos felsôoktatási kiadásainak átlaga 1,355\%. Magyarország felsôoktatási kiadásai az átlagos érték alatt maradnak, ugyanakkor a visegrádi országok mindegyikének jobb az eredménye. A nemzetközi összehasonlítás alapján vegyes körkép körvonalazódik: a felsôoktatásra legtöbbet költố európai országnak az Egyesült Királyság tekinthetô 1,868\%-os GDP-arányos kiadással, ugyanakkor Luxemburgban a legalacsonyabb $(0,527 \%)$ ez a mutató.

\section{A MAGYAR FELSÓOKTATÁSI SZEKTOR A SZÁMOK TÜKRÉBEN}

A magyarországi felsôoktatási szektor nagyságát jól szemlélteti a felsôoktatási intézmények száma és a felsőfokú képzésben részt vevô hallgatói létszám.

Magyarországon jelenleg 64 felsôoktatási intézmény kínál különféle felsőfokú képzést. A felsőfokú képzési kínálatban egyaránt megjelenik a felsôfokú szakképzés, felsôfokú alapképzés (bachelor), mesterképzés (master) és a felsôfokú továbbképzés. A 64 intézményből 28 állami, 22 egyházi, 14 pedig alapítványi, illetve természetes személy általi fenntartású. A 2017/2018-as tanévben 23110 fố dolgozott oktatóként, ami 3\%-kal meghaladja az elôzó évi oktatói létszámot (3. ábra).

A felsôoktatásban továbbtanuló hallgatói létszám folyamatos, évenkénti csökkenésének lehetünk szemtanúi, míg az oktatói létszám, ha kismértékben is, de az elmúlt két évben növekedésnek indult a korábbi 


\section{Tudományos múhely}

1. táblázat: A költségvetés oktatási kiadásai (2001-2016)

\begin{tabular}{c|c|c|c|c|c}
\hline \multirow{2}{*}{ Év } & $\begin{array}{c}\text { Felsófokú oktatási } \\
\text { kiadások }\end{array}$ & $\begin{array}{c}\text { Oktatási kiadások } \\
\text { összesen }\end{array}$ & $\begin{array}{c}\text { GDP értéke, } \\
\text { folyó áron, } \\
\text { Mrd Ft }\end{array}$ & $\begin{array}{c}\text { Felsófokú oktatási } \\
\text { kiadások/GDP, } \\
\%\end{array}$ & $\begin{array}{c}\text { Összes } \\
\text { oktatás/GDP, } \\
\%\end{array}$ \\
\hline 2001 & 161871 & 770879 & 15419,1 & 1,05 & 5,00 \\
\hline 2002 & 183934 & 932529 & 17461,7 & 1,05 & 5,34 \\
\hline 2003 & 216422 & 1071456 & 19138,9 & 1,13 & 5,60 \\
\hline 2004 & 214129 & 1089090 & 21099,1 & 1,01 & 5,16 \\
\hline 2005 & 226772 & 1170113 & 22559,9 & 1,01 & 5,19 \\
\hline 2006 & 234968 & 1216135 & 24257,0 & 0,97 & 5,01 \\
\hline 2007 & 253174 & 1228401 & 25680,2 & 0,99 & 4,78 \\
\hline 2008 & 266745 & 1275107 & 27193,6 & 0,98 & 4,69 \\
\hline 2009 & 261763 & 1237224 & 26424,6 & 0,99 & 4,68 \\
\hline 2010 & 259156 & 1262749 & 27224,6 & 0,95 & 4,64 \\
\hline 2011 & 270646 & 1211562 & 28304,9 & 0,96 & 4,28 \\
\hline 2012 & 247517 & 1153755 & 28781,1 & 0,86 & 4,01 \\
\hline 2013 & 243645 & 1142329 & 30247,1 & 0,81 & 3,78 \\
\hline 2014 & 257908 & 1370978 & 32591,7 & 0,79 & 4,21 \\
\hline 2015 & 264484 & 1480450 & 34324,1 & 0,77 & 4,31 \\
\hline 2016 & 300297 & 1552767 & 35420,3 & 0,85 & 4,38 \\
\hline
\end{tabular}

Forrás: $\mathrm{KSH}$

1. ábra: A felsôoktatási kiadások a GDP \%-ban nemzetközi összehasonlításban (2016)

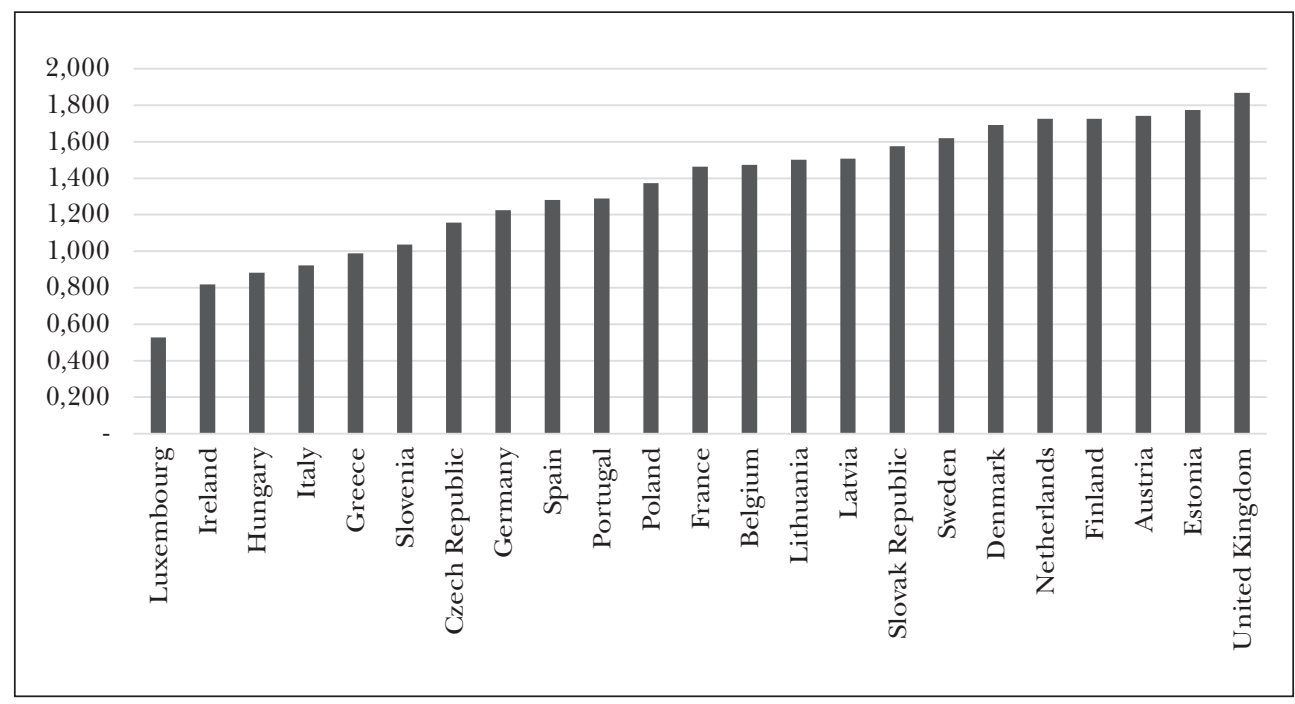

Forrás: OECD, 2016 
2. ábra: Felsôoktatási intézmények száma

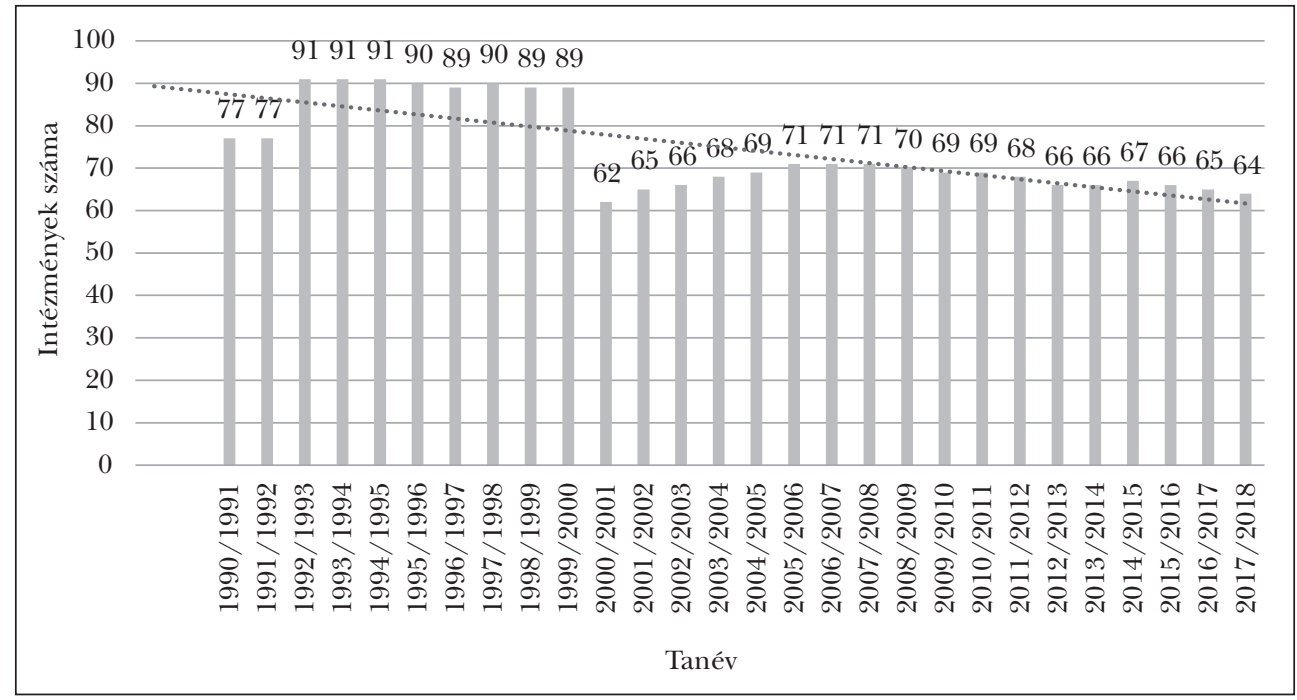

Forrás: Saját szerkesztés a KSH adatai alapján

folyamattal ellentétesen. A hallgatói létszámcsökkenés hátterében egyrészt demográfiai okok állnak (folyamatosan csökken a születések száma), de nem hagyhatók figyelmen kívül a szektor finanszírozási rendszerében bekövetkezett változások sem. Ezen változások eredményeképpen jelentôsen lecsökkent az államilag finanszírozott férôhelyek száma, az önköltséges férôhelyek növekedésével párhuzamosan.

3. ábra: Felsốoktatási oktatói és hallgatói létszám

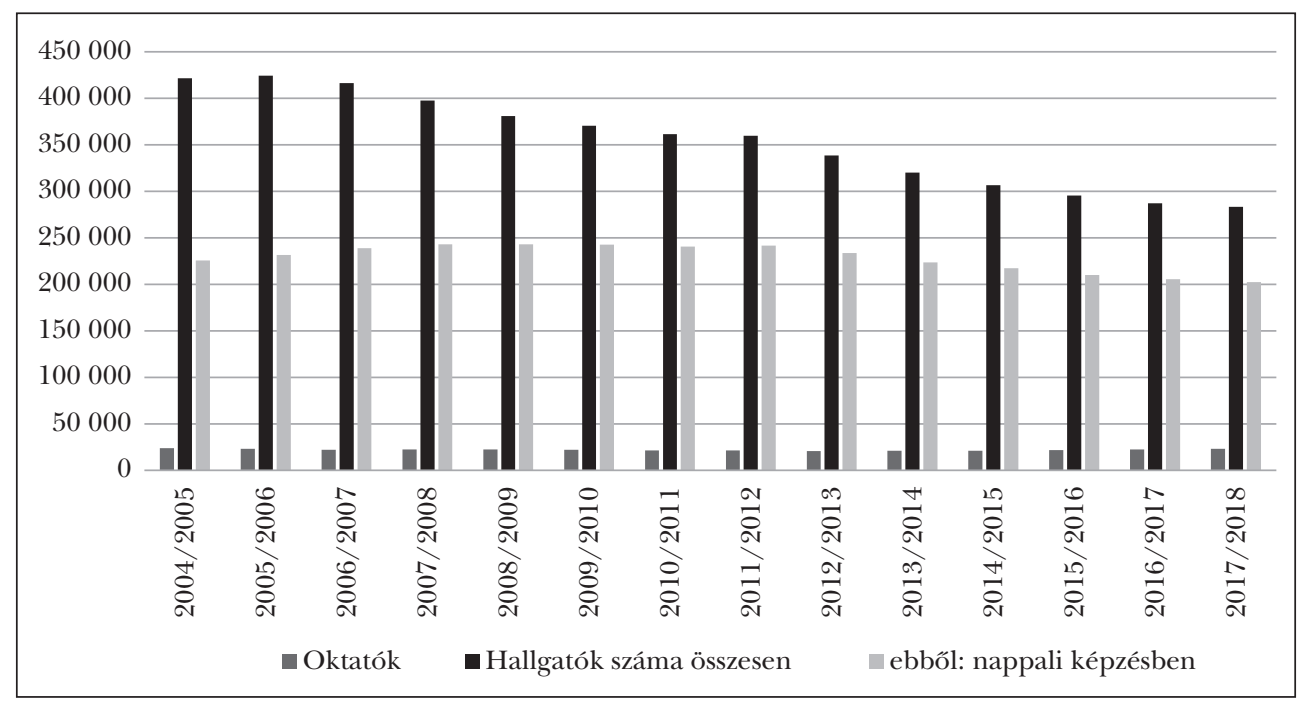

Forrás: Saját szerkesztés a KSH adatai alapján 


\section{Tudományos múhely}

Mindezen hatások eredőjeként, vagyis a viszonylag magas felsôoktatási intézményszám és a csökkenố továbbtanulásra jogosulti létszám együttesen erôs versenyhelyzetet teremtett a szereplók között Magyarországon. A hallgatókért folyó verseny pedig állandó megújulásra, innovációra kényszeríti a felsôoktatási intézményeket. Az intézmények mint szolgáltatók lépnek fel, ahol a hallgatók a képzéseket igénybe vevô „ügyfelek”-ként azonosíthatók.

\section{A gAZDASÁGTUDOMÁNYI KÉPZÉS HAZÁNKBAN}

Az állami férôhelyek számának drasztikus csökkentése és a 2012. évi ponthatár-szigorítás kiemelten a gazdaságtudományi képzési terület szakjait érintette. Az azóta eltelt idó adatai azonban megerôsítik azt a tényt, hogy az akkori várakozásokkal ellentétben ezek a képzések jelentős mértékben nem veszítettek a népszerúségükból. Az összes felvételt nyert hallgatói létszám 2013 és 2016 között 13 százalékkal csökkent, míg a gazdaságtudományi képzési területre felvettek létszáma mindössze 10 százalékos csökkenést mutat ezen idôszakban, a 2012. bázisévhez viszonyítva. A Felvi.hu szerint 2017-ben a gazdaságtudományi képzési terület volt a legnépszerúbb és egyúttal a legnépesebb képzési terület is, az alapképzésre felvett több mint 9200 hallgatóval és közel 13500 elsố helyes jelentkezôvel. Ezen a képzési területen 35 intézmény hirdetett meg alap- és osztatlan mesterképzési szakokat.

Az elmúlt évek felvételi statisztikai adatai alapján megállapíthatjuk, hogy az alapszakok közül a legtöbben elsố helyen a gazdaságtudományi, a múszaki és a pedagógus képzési terület valamely szakját jelölték meg (2. táblázat). A legnépszerúbb alapképzésnek elsố helyen a gazdálkodási és menedzsment, második helyen a mérnökinformatikus, harmadik helyen pedig az ápolás és betegellátás képzés bizonyult 2018-ban (3. táblázat). Az informatikai képzési területrôl a legnépszerúbb alapképzések között a mérnökinformatikus mellett a programtervezô informatikus képzés, a múszaki képzési területrôl pedig a gépészmérnök képzés is szerepel. A pénzügy-számvitel alapszak 2016-ban a 9. helyen szerepelt, 2017-ben és 2018-ban már nincs az elsố tíz között. Ez a rangsor is jelzi a $\mathrm{Z}$ generáció pénzügyiszámviteli szakmával kapcsolatos attitúdjét.

\section{Az „OKTATÁS” KIHÍVÁSAI \\ A GAZDASÁGTUDOMÁNYI KÉPZÉSI TERÜLETEN}

Napjaink egyik fő kihívása, hogy a munkahelyeken új elvárásokkal szembesülnek a munkavállalók, az élethosszig tartó tanulás igénye mellett a teammunka, azaz meghatározott csoportban végzett tevékenység ellátásának nehézségeivel, amelyre az oktatási rendszerünk kevéssé készít fel.

A munkaadók elvárásai között szerepel, hogy a munkavállalók idegennyelv-tudással rendelkezzenek, és alapkövetelmény az informatikai jártasság, hiszen enélkül napjainkban már lehetetlen boldogulni. Az üzleti világban, különösen a számvitel, pénzügy területén is nélkülözhetetlen a digitális technikák ismerete. Tekintettel arra, hogy a számvitel digitalizációja elképesztô sebességgel zajlik, különösen fontossá vált ebben az „információáradatban a célorientált, kritikus válogatás, az adatok és az információk keresésének, olvasásának, értelmezésének a képessége" (Sándorné, 2018).

Gyakran halljuk, hogy kompetenciaalapú oktatásra van szükség. De mi is az a kompetencia, hogyan lehet az oktatás-módszertani fejlesztések során figyelembe venni? A kompetencia alkotóelemei: tudás, jártasság, attitúdök, személyes értékek, személyes vonások, motivációk.

A felsôoktatásban a szemináriumon belül kialakítható tevékenység a csoportmunka, többek között esettanulmányok, projektmunkák kidolgozása mentén, amely erôsítheti a hallgatókban a kapcsolatteremtést, az együttmúködést, a lényeglátást, a kreativitást, az önálló vélemény kialakítá- 
2. táblázat: Elsố helyes jelentkezések száma a legnépszerúbb képzési területeken, alapképzésben és osztatlan mesterképzésen

\begin{tabular}{l|c|c}
\hline Képzési terület & $\mathbf{2 0 1 7}$ & $\mathbf{2 0 1 8}$ \\
\hline gazdaságtudományok & $16,30 \%$ & $17,10 \%$ \\
\hline múszaki & $13,50 \%$ & $13,80 \%$ \\
\hline pedagógusképzés & $14,10 \%$ & $13,70 \%$ \\
\hline informatika & $8,80 \%$ & $9,80 \%$ \\
\hline orvos- és egészségtudomány & $9,30 \%$ & $8,90 \%$ \\
\hline bölcsészettudomány & $8,10 \%$ & $8,60 \%$ \\
\hline jogi & $5,10 \%$ & $4,80 \%$ \\
\hline
\end{tabular}

Forrás: Felvi.hu

3. táblázat: Az elsó helyes jelentkezések rangsora alapképzések szerint 2016 és 2018 között

\begin{tabular}{l|c|c|c|c|c|c}
\hline \multirow{2}{*}{ Szak neve } & $\begin{array}{c}\text { Elsó helyes } \\
\text { jelentkezók } \\
\text { száma }\end{array}$ & Rangsor & $\begin{array}{c}\text { Elsó helyes } \\
\text { jelentkezók } \\
\text { száma }\end{array}$ & Rangsor & $\begin{array}{c}\text { Elsó helyes } \\
\text { jelentkezók } \\
\text { száma }\end{array}$ & Rangsor \\
\cline { 2 - 7 } & \multicolumn{2}{|c|}{$\mathbf{2 0 1 6}$} & \multicolumn{2}{|c}{$\mathbf{2 0 1 7}$} & \multicolumn{2}{c}{$\mathbf{2 0 1 8}$} \\
\hline $\begin{array}{l}\text { gazdálkodási és } \\
\text { menedzsment }\end{array}$ & 3879 & 1 & 3827 & 1 & 4220 & 1 \\
\hline $\begin{array}{l}\text { mérnök- } \\
\text { informatikus }\end{array}$ & 3045 & 3 & 3327 & 2 & 3579 & 2 \\
\hline $\begin{array}{l}\text { ápolás és } \\
\text { betegellátás }\end{array}$ & 2884 & 5 & 3260 & 4 & 3278 & 3 \\
\hline $\begin{array}{l}\text { óvodapedagógus } \\
\text { pszichológia }\end{array}$ & 28475 & 2 & 3277 & 3 & 3158 & 4 \\
\hline gépészmérnöki & 2974 & 4 & 2656 & 5 & 2737 & 6 \\
\hline $\begin{array}{l}\text { kéreskedelem } \\
\text { és marketing }\end{array}$ & 2431 & 8 & 2233 & 9 & 2572 & 7 \\
\hline $\begin{array}{l}\text { gyógypedagógia } \\
\text { turizmus- } \\
\text { vendéglátás }\end{array}$ & 1703 & 12 & 2259 & 8 & 2486 & 8 \\
\hline $\begin{array}{l}\text { programtervezó } \\
\text { informatikus }\end{array}$ & 1955 & 11 & 2207 & 10 & 2320 & 10 \\
\hline
\end{tabular}

\section{Forrás: Saját szerkesztés a Felvi.hu adatai alapján}

sának kompetenciáit. Az adott foglalkozás résztvevői kisebb, 2-5 fốs csoportokban, együttmúködve oldják meg a feladatokat, majd prezentáció keretében beszámolnak az eredményeikről, amelynek kiértékelése egy beszélgetés, esetleg vita keretében történik.

A csoport munkáját maguk a résztvevôk irányítják, ôk alakítják ki az együttmúködés kereteit, amely kereteknek a továbbiakban meg kell felelniük. Ez az egyik legjobb módja a tapasztalati úton történố tanulásnak, mert

- meg kell oldaniuk a saját feladatukat;

- prezentálni kell a kapott eredményeket;

- elemezni kell mind a saját, mind a többi csoport munkáját. 


\section{Tudományos múhely}

A csoportmunka az oktatásban fóként a mesterképzésben, illetve az alapképzés felsóbb évfolyamainak tantárgyai keretében valósul meg. Az alapozó tárgyak esetében a hagyományos tantermi oktatás mellett elearninges tananyagok kidolgozásával nyújtanak segítséget a felkészüléshez, illetve online példatárak hozzák közelebb a hallgatót az ismeretek elsajátításához.

Az oktatás módszertani fejlesztéseinek választ kell adniuk korunk új kihívásaira, a $\mathrm{Z}$ generáció igényeihez igazodva, felkeltve érdeklődésüket, fenntartva motivációjukat. Ehhez az oktatói hozzáállás változására is szükség van. Elengedhetetlen az infrastrukturális fejlesztés és az oktatói oldal szemléletváltása, tekintettel a jelentôsen megváltozott hallgatói elvárásokra és attitúdökre, illetve képességekre.

\section{A SZÁMVITELI FELSÔOKTATÁS A GAZDASÁGTUDOMÁNYI KÉPZÉSBEN}

A továbbiakban a pénzügy és számvitel alapszak, illetve a rá épüló számvitel mesterszak struktúráján keresztül kerül mutatjuk be a számviteli felsôoktatás gyakorlatát, a módszertani alkalmazásokat, a bennük rejló lehetôségeket a változó környezethez való alkalmazkodásra, a fenntarthatóság erôsítésére.

A pénzügy és számvitel alapképzési szak képzési célja

A pénzügy és számvitel alapszak képzési célja pénzügyi és számviteli szakemberek képzése, akik korszerú, nemzetközi követelményeknek megfelelô közgazdasági múveltséggel, pénzügyi és számviteli alkalmazásokhoz elméleti ténybeli és módszertani ismeretekkel rendelkeznek, képesek az adatok valósághú elóállítására, hasznosítására, a tudástôke mint szervezeti vagyon gyarapítására, a pénzügyi és számviteli rendszerek átlátására, múködtetésére, fejlesztésére, stratégiai döntések meghozatalára, korszerú tervezési, gazdálkodási, elszámolási, kontrollingeljárások és -módszerek alkalmazására, az intézményi feltételek formálására, nemzetközi, országos és regionális vállalkozások információs rendszerének áttekintésére, múködtetésére, fejlesztési céljainak megvalósítását szolgáló helyzetfelmérésre és javaslattételre, az érdekegyeztetési folyamatok koordinálására, és felkészültek a tanulmányaik mesterképzésben történô folytatására.

\section{Szakmai jellemzők}

A szakképzettséghez vezetố tudományágak, szakterületek, amelyekból a szak felépül:

- közgazdaságtani, módszertani és üzleti ismeretek (matematika, statisztika, informatika, mikro- és makroökonómia, nemzetközi gazdaságtan, pénzügytan, vállalati gazdaságtan, gazdasági jog, marketing, számvitel, menedzsment, üzleti kommunikáció, szaknyelv, környezet-gazdaságtan, egyéb alapozó üzleti ismeretek);

- társadalomtudományi ismeretek (európai uniós, általános és gazdasági jogi ismeretek, gazdaságtörténet, szociológia, pszichológia, filozófia);

- pénzügyi és számviteli szakmai ismeretek (pénzügyek, jog, pénzügyi számítások és pénzügyi piacok, adózási ismeretek, vállalatértékelés, pénzügyi számvitel, vezetôi számvitel alapjai, elemzés-ellenôrzés módszertana, üzleti tervezés, a pénzügyi és számviteli informatika, sajátos számviteli esetek elszámolására vonatkozó ismeretek, továbbá választható specializációk).

A pénzügyi és számviteli szak gyakorlatorientált képzési szerkezetú, ami azt jelenti, hogy az összes oktatott tantárgy körülbelül 60-70 százalékát gyakorlati jeggyel záruló tantárgy teljesítésével lehet megszerezni. Az elméleti oktatási féléveket egy szemeszter hosszúságú szakmai gyakorlati félév zárja le, ahol a hallgató megismerheti a szakterületén folyó, a gyakorlati életben alkalmazott konkrét eljárásokat, módszertanokat. Ez a félév szolgál a szakdolgozat elkészítésére is. 


\section{Tudományos múhely}

\section{A számvitel mesterszak képzési célja}

A képzés célja számviteli szakemberek képzése, akik a nemzetközi összehasonlításban versenyképes, korszerú elméleti és gyakorlati ismeretek birtokában képesek a gazdálkodó egységek számviteli folyamatainak irányítására, ellenôrzésére és elemzésére. Elméleti és gyakorlati, üzleti és módszertani ismereteik, a tudatosan fejlesztett vezetói készségek és képességek birtokában alkalmasak a hazai és a nemzetközi gazdasági élet különbözó területein közép- és felsố vezetôi feladatok ellátására, a számvitel nemzetközi és hazai szakirodalmának feldolgozására, annak gazdagítására, továbbá felkészültek a tanulmányaik doktori képzésben történő folytatására.

\section{A siker kulcsa?}

A Magyarországon folyó, magyar - állami - felsôoktatási intézmények küldetése, az Alaptörvényben foglalt hitvallás szerint, az egyetemi polgárrá váló fiatal nemzedékek elhivatottságának, tehetségének és kitartásának kiaknázásán keresztül megerôsíteni a magyar társadalmat és ezen keresztül az ország gazdasági teljesítôképességét. Az oktatási rendszer legmagasabb szintjén folyó felsőoktatás konkrét célja a felsôoktatás színvonalának emelése, folyamatos fejlesztése, par excellence a versenyképes tudás átadásához és megszerzéséhez szükséges feltételrendszer megteremtése. A szükséges feltételrendszer komplex és zárt rendszer, melynek kiemelt szereplôi a „szolgáltató egyetemek” és a szolgáltatást igénybe vevố hallgatók. Úgy véljük, hogy a felsôoktatási célok sikeres teljesítésének egyik legnagyobb korlátja ma Magyarországon - és nemzetközi tapasztalatok alapján kijelenthetjük, hogy szerte a világon - a Z generációból kikerülő hallgatók attitúdje, készségei és képességei, motivációi. Az elmúlt évek felvételi statisztikai adatai alapján a pénzügy és számvitel alapszakra felvételizók, illetve felvettek száma folyamatos csökkenést mutat, ugyanakkor a számvitelt tanuló hallgatók számviteli szakma iránti elkötelezettsége, motivációja is egyre alacsonyabb. Mindezek eredôjeként a számviteli szakma presztízsértéke is csökkenô tendenciát mutat. Hiába törekednek az egyetemek az oktatási módszerek és tartalmak folyamatos megújítására, fejlesztésére, ha nincsenek nyitott, motivált és terhelhetó, tanulni akaró hallgatói. Véleményünk szerint az oktatóintézmények célkitûzései és a hallgatók elvárásai, attitúdjei között egyre nagyobb „rés” (gap) kezd kialakulni, ami oly módon csökkenthetô, ha megpróbáljuk megismerni és megérteni a szolgáltatást igénybe vevôk preferenciarendszerét és attitúdjét.

A képzések során fontosnak tartjuk a folyamatos megújulást, a számviteli szakma presztízsének helyreállítását, a számviteli életpálya népszerúsítését. Ennek egyik kulcspontja a szakma jeles képviselóivel való intenzív kapcsolattartás, melynek keretében nemcsak arról tájékozódhatunk, hogy mit igényel a szakma, milyen elvárásokkal rendelkezik a friss diplomások tekintetében, de beépülve az oktatásba, a hallgatók számára „behozzák a valóságot” az elôadótermekbe, szemináriumi helyiségekbe, bemutatva a karrierlehetôségeket is.

\section{ÖsszeGzÉS}

Figyelembe véve a már lezajlott és folyamatban lévô változásokat a magyarországi felsôoktatásban, úgy ítéljük meg, hogy a fenntartható felsôoktatáshoz további innovációra, módszertani paradigmaváltásra van szükség. Értelmezésünkben a minôségi felsôoktatás alatt olyan oktatási folyamatot értünk, ahol a szereplók - oktató és oktatott - kölcsönös érdekeltségébôl és motivációjából fakadóan a felsôoktatás úgy képes folyamatosan megújulni, hogy az oktatási színvonal nem csökken. A minôség elsôdleges felelôse az intézmény, következésképpen az intézményi stratégia része kell hogy legyen a minőségi felsôoktatásra való állandó törekvés. Ugyanakkor a minôség biztosításának, illetve fenntartásának vitathatatlanul fontos befolyásoló tényezője maga a hallgató. 


\section{Tudományos múhely}

\section{FELHASZnÁlt IRODALOM}

Bazsa György (2014): A minôségügy és az akkreditáció. Educatio, 23. évf., 1. sz., 93-107.

Brown, Malcolm (2003): Learning spaces. Educause Quarterly, No. 1, 14-16, www.educause.edu/research-and-publications/books/educating-net-generation/learning-spaces.

Czeglédi Csilla - Marosné Kuna Zsuzsanna - Kollár Péter - Miskolciné Mikáczó Andrea - Varga Erika - Zéman Zoltán (2016): A vállalkozói ismeretek oktatásának helyzete a magyar felsôoktatásban. Polgári Szemle, 12. évf., 1-3. sz.

Máté, Domicián - Darabos, Éva (2017): Measuring the Accuracy of Self-assessment Among Undergraduate Students in Higher Education to Enhance Competitiveness. Journal of Competitiveness, Vol. 9, No. 2, 78-92, https://doi. org/10.7441/joc.2017.02.06.

Falus Iván (szerk.) (1999): Didaktika. Tankönyvkiadó, Budapest.

Falus Iván - Környei László - Németh Szilvia - Sallai Éva (szerk.) (2012): A pedagógiai rendszer. Fejlesztôk és felhasználók kézikönyve. Educatio Társadalmi Szolgáltató Nonprofit Kft., Budapest, http:// documents.tips/documents/a-pedagogiai-rendszer.html.

Gandossy, Robert - Tucker, Elissa (2007): Gazdálkodj okosan - a tehetséggel. HVG Könyvek, Budapest.

Hegedús Henrik (2015): XXI. századi kihívások.
HR-megoldások a köz- és a versenyszférában. Hadtudomány (online), 25. évf., 102-107.

Kiss Árpád - Lukács János (2017): A számvitel és a menedzseri tudásháló kapcsolata. Controller Info, Vol. 5, No. 3, 2-6.

Miskolczi Ildikó (2010): Tanulás vagy e-tanulás? Oktatásmódszertan a XXI. században. Szolnoki Tudományos Közlemények XIV., Szolnok.

OECD (2016): Education Spending. OECD, https:// data.oecd.org/eduresource/education-spending.htm.

Prensky, Marc (2001): Digital Natives, Digital Immigrants, Part 1. On the Horizon, Vol. 9, No. 5, https://doi.org/10.1108/10748120110424816.

Sándorné Kriszt Éva (2018): A statisztika oktatásának helye és szerepe a magyar felsôoktatásban. Statisztikai Szemle, 96. évf., 3. sz., 255-273, https://doi.org/10.20311/stat2018.03.hu0255.

Siklósi Ágnes - Sisa Krisztina A. (2017): Innováció és fenntarthatóság a hazai számviteli felsôoktatásban. Controller Info, 5. évf., 3. sz., 42-50.

Takács András (2017): A pénzügyi teljesítmény és a piaci elfogadottság hatása a nemzetközi feldolgozóipari, valamint szolgáltatóvállalatok részvényáraira. Statisztikai Szemle, 95. évf., 7. sz., 726-743, https://doi.org/10.20311/stat2017.07.hu0726.

1536/2016. (X. 13.) Korm. határozat a köznevelési, a szakképzési, a felsôoktatási és a felnôttképzési rendszer digitális átalakításáról és Magyarország Digitális Oktatási Stratégiájáról. 